Omni-Akuatika, 14 (3): 66-74, 2018
ISSN: 1858-3873 print / 2476-9347 online
Research Article
journal homepage: http://ojs.omniakuatika.net

\title{
Moina sp. Powder Supplementation as Artemia sp. Substitute through Growth, Lysine,Histidine, Methionine, and Leucine Amino Acid Contents in Tiger Grouper X Camouflage Grouper Hybrid Larvae (Epinephelus fuscoguttatus $x$ Epinephelus microdon)
}

\author{
Arga Iswara ${ }^{1,{ }^{\star}}$, Frida Choirun Nisa, ${ }^{, 1}$, Nofita Irmayani Herlambang ${ }^{1}$, Shobrina Silmi Qori Tartila ${ }^{1 \star}$ \\ Mochammad Amin Alamsjah ${ }^{2}$, Agustono $^{3}$ \\ ${ }^{1}$ Aquaculture, Faculty of Fisheries and Marine Universitas Airlangga, Surabaya 60115, Indoensia \\ ${ }^{2}$ Department of Marine, Faculty of Fisheries and Marine Universitas Airlangga, Surabaya 60115, Indoensia \\ ${ }^{3}$ Department of Fish Health Management and Aquaculture, Faculty of Fisheries and Marine \\ Universitas Airlangga, Surabaya 60115, Indoensia \\ *Correspondence: shobrina.silmi-13@fpk.unair.ac.id
}

Received 29 March 2018; Accepted 25 November 2018; Available online 30 November 2018

\begin{abstract}
Tiger Grouper x Cammouflage Grouper (TGCG) (Epinephelus fuscoguttatus x Epinephelus microdon) production is still low nowadays due to the insufficient price of the live feed supply during the larval phase, which is nauplii Artemia sp. One of the live feed types which is able to become a substitute of nauplii Artemia sp. is Moina sp., which has better lysine, histidine, methionine, and leucine contents, besides having the sufficient price for the supply itself. However, Moina sp. is unable to survive in the high salinity, thus it has to be produced as a powder. This condition leads to a further research whether to observe that the Moina sp. powder supplementation is able to become nauplii Artemia sp. substitute through the increased growth and the optimum better lysine, histidine, methionine, and leucine contents in TGCG larvae. The research was conducted using the complete randomized design experimental method. The result showed that Moina sp. powder is compatible as good substitute candidate of nauplii Artemia sp., as it increased the larval length growth, even it had no difference in weight growth, but it was also able to increase the larval lysine, histidine, methionine, and leucine contents.
\end{abstract}

Keywords : TGCG, Nauplii Artemia sp., Moina sp. powder, growth, lysine, histidine, methionine, leucine

\section{Introduction}

Tiger grouper $\times$ Cammouflage grouper (TGCG) fish is a cross-breeding fish hybridization of the male cammouflage grouper (Epinephelus microdon) and the female tiger grouper (Epinephelus fuscoguttatus) (Ismi et al., 2014). The TGCG fish breeding business has yet to be developed and widely applied. One factor that influenced the breeding business success is the live feed supply, because it had become the limited factor during the larval rearing (Sari and Manan, 2012). The lack of live feed supply with the higher price could cause the low production of the breeding business. The Artemia sp. nauplii supply, which is part of the live feed given during the larval rearing, often has problem, because it is still obtained commercially in the form of cysts and has insufficient price. Therefore, the larval production costed a lot more to fulfill the nauplii Artemia sp. supply (Ismi et al., 2013).

Nauplii Artemia sp. Also had a low nutrient contents. Ovie and Ovie (2006) mentioned that Nauplii Artemia sp. had low levels of amino acid contents, such as lysine, histidine, methionine and leucine. Histidine was used as supporting the larval growth, body tissue repairing, and supporting the red blood cells production (Selcuk et al., 2010 in Purwaningsih et al., 2013). Lysine was acted as the growth enhancement, promoting larval development, increasing the larval survival rate, and determining the feed quality ( $\mathrm{Li}$ et al., 2008). Methionine had function to optimize the normal growth and metabolism. The deficiency of methionine showed low growth and bilateral cataract, besides causing the low feed efficiency in rainbow trout fish (Walton et al., 1982). Leucine helped the formation of muscle mass and skin, especially accelerating post-operative wound healing (Harli, 2008). 
The high supplied cost of Artemia sp. cysts followed with the low nutrient contents makes it compatible to be substituted using another live feed that has the same or better nutrients content compared with Artemia sp. According to Arief et al. (2009), choosing a feed, especially as a substitute feed, had to be based on the good feed requirement, such as the high nutrient contents, easy to get, relatively in low cost, easy to digest, and unpoisoned. One of the live feed that could become the substitute candidate of Artemia sp. Is Moina sp., which had higher level of amino acid contents, compared with Artemia sp. (Ovie and Ovie, 2006).

Moina sp. has still yet to be given to the marine fish larvae, since Moina sp. was unable to live longer in the high salinity, which was 30-34 ppt (Sugama et al., 2013). One way to make Moina sp. as a substitute candidate of Artemia sp. is by producing it as a powder after drying it out with the size $200-400 \mu \mathrm{m}$, which were the same size of the commercial feed given to marine larvae (Reed Mariculture Inc., 2003). A further research needs to be conducted to determine whether Moina sp. powder will be able to increase the growth and the amino acid contents, besides expecting to lower the production cost during the larval rearing of TCGC.

\section{Materials and Method}

\subsection{Time and place}

This research was held in the Faculty of Fisheries and Marine Laboratories Universitas Airlangga, Faculty of Veterinary Medicine Animal Science Laboratory Universitas Airlangga, Politeknik Kesehatan Kementerian Kesehatan Testing Laboratory Surabaya, and CV. Dewata Laut Bali on March until May 2017.

\subsection{Tools and materials}

The equipment used in this research was a box of styrofoam, 20 pieces of approximately $20 \mathrm{~L}$ Aquarium, one piece of $500 \mathrm{~L}$ of fiber tank, aerator, aerator hose, filter bag, tube, thermometer, marine water supply, DO test kit, $\quad \mathrm{pH}$ test kit, Ammonium test kit, analytical scale, and ruler. The materials used in this research were the TGCG larvae, which reached the age of 24 days after hatching (D-24) and were obtained from CV. Dewata Laut. Moina sp. Was prepared in the frozen form, thus necessary to be dried out in advance. The melted Moina sp. were soon to be dried in the oven and grinded as powder (Vandamme, 2013). The
Nauplii Artemia sp. were prepared by hatching off the Artemia sp. cysts.

\subsection{Treatment}

This research used the completed randomized design for the experimental method with 5 different feed doze and 4 replications. The fifth different doze were the control doze $(K)$ (80\% commercial feed and $20 \%$ nauplii Artemia $s p$.$) , the first doze (P1) (80 \%$ commercial feed, $15 \%$ nauplii Artemia sp., and 5\% Moina sp. powder), the second doze (P2) ( $80 \%$ commercial feed, $10 \%$ nauplii Artemia sp., and 10\% Moina sp. powder), the third doze (P3) $(80 \%$ commercial feed, $5 \%$ nauplii Artemia sp., and $15 \%$ Moina sp. powder), and the fourth doze (P4) (80\% commercial feed and $20 \%$ Moina sp. powder).

\subsection{Research procedure}

Aquariums were cleaned using chlorine and sodium thiosulfat with the ratio $2: 5$ or 0.5 $\mathrm{mg} . \mathrm{L}^{-1}$ doze of chlorine and $1.25 \mathrm{mg} \cdot \mathrm{L}^{-1}$ doze of sodium thiosulfate. The Aquarium were dried for 24 hours. The Aquariums were settled followed the aeration setting. Aquariums were filled with the sterile sea water that had been filtered using $10 \mu \mathrm{m}$ mesh size of filter bag (Creswell, 2010). Aquariums that had been filled with marine water, were given phytoplankton Nannocholoropsis oculata under the density of $3.507 \times 10^{5}$ cells $/ \mathrm{ml}$.

The TGCG larvae were stocked at the Aquariums. The larvae obtained had to be healthy and away from any disease. The larvae were gently stocked on the aquariums with the stocking density of 20 larvae in each aquariums (Sim et al., 2005).

\subsection{Moina sp. powder production}

The Moina sp. powder production started by melting the frozen Moina sp. until becoming more fluid. The Moinasp. were moved to the oven for drying out in 24-48 hours under the temperature of $40-60^{\circ} \mathrm{C}$ (Bilad et al., 2012 in Vandamme, 2013). The dried Moina sp. was grinded using a grinder machine until reaching 200-400 $\mu \mathrm{m}$ in size (Sugama et al., 2013).

\subsection{Water quality}

The optimum water quality needed during the research was $28-30^{\circ} \mathrm{C}$ in temperature, $32-34 \%$ in water salinity, $>4 \mathrm{mg} \cdot \mathrm{L}^{-1}$ in the dissolved oxygen content, 8-8.2 in $\mathrm{pH},<0.3$ mg. - $^{-1}$ in the ammonia content (Ismi, 2014; WWF Indonesia, 2015). The water quality was controlled before larvae were stocked at the aquariums and during the research. 


\subsection{Larval growth}

The larval growth was determined by measuring the length and the weight of the entire sampled larvae, before and after the treatment given. The larval length and weight data obtained were calculated through the formula of absolute and specific growth rate. According to Hopkins (1992) and Martin et al. (2015), the absolute and specific growth rate formulas were:

$$
\begin{aligned}
& G R(L)=\frac{L_{t}-L_{0}}{t} \\
& G R(W)=\frac{W_{t}-W_{0}}{t} \\
& \operatorname{SGR}(L)=\frac{\ln \left(L_{t}\right)-\ln \left(L_{0}\right)}{t} \times 100 \% \\
& \operatorname{SGR}(W)=\frac{\ln \left(W_{t}\right)-\ln \left(W_{0}\right)}{t} \times 100 \%
\end{aligned}
$$

Note :

$\mathrm{GR}(\mathrm{L})=$ Length Growth Rate (cm.day ${ }^{-1}$ )

GR (W) $=$ Weight Growth Rate (g.day ${ }^{-1}$ )

SGR $(\mathrm{L})=$ Length Specific Growth

Rate $\left(\%\right.$.day $\left.{ }^{-1}\right)$

SGR $(W)=$ Weight Specific Growth

Rate $\left(\%\right.$. day $\left.^{-1}\right)$

$\mathrm{t} \quad=$ Research Time

$\mathrm{L}_{0} \quad=$ Initial Larval Length $(\mathrm{cm})$

$\mathrm{L}_{\mathrm{t}} \quad=$ Final Larval Length $(\mathrm{cm})$

$\mathrm{W}_{0} \quad=$ Initial Larval Weight $(\mathrm{g})$

$\mathrm{W}_{\mathrm{t}} \quad=$ Final Larval Weight $(\mathrm{g})$

\subsection{Larvae amino acid contents analysis}

The amino acid contents in TGCG larvae before and after the treatment given were analyzed using HPLC (High Performance Liquid Chromatography). HPLC analysis required larval samples that had been drained off until it weighed 0.1-0.2 g. The sampled larvae were homogenized using 0.07 $\mathrm{M} \quad \mathrm{Na}_{3} \mathrm{PO}_{4}$ buffer solution and were deproteinetized with sulfosalisilic acid under the ratio 1:1 with $\mathrm{Na}_{3} \mathrm{PO}_{4}$. The deproteinetized sample would yield a solution of free amino acids that were dissolved (pre-derivation) in phenil isothiosianate (FITS) (Berge et al., 1998). The dissolved samples were taken as much as taken $20 \mu \mathrm{L}$ using a syringe and were injected on the HPLC machine. The result of the amino acid contents read by the HPLC machine would be in the form of chromatography diagram (Chairunisah, 2011).

\section{Result}

\subsection{Larval length growth}

The absolute and specific growth length of TGCG larvae showed (Table 1) that there was no significant difference $(p>0.05)$. However, the best treatment was presented on the $\mathrm{P} 4$ and the lowest growth rate results found in treatment P1 with siginificant difference against $\mathrm{P} 4$, but showing no significant difference in P2, P3, and $\mathrm{K}$.

\subsection{Larval weight growth}

The weight growth of TGCG larvae showed in Table 2. There was no significant difference both in the absolute and the spesific growth rate $(p>0.05)$. However, P4 showed the highest growth rate, whereas P1 was the lowest growth rate.

\subsection{Larval amino acid contents}

The amino acid contents (Lysine, Methionine, Histidine, and Leucine) in TGCG larvae showed in Figure 1. The significant increase occured after the treatment given, compared with the initial content before the treatment given. The highest level in

\begin{tabular}{|c|c|c|c|c|}
\hline Treatment & Initial $\left(\mathrm{H}_{0}\right)(\mathrm{cm})$ & Final $\left(\mathrm{H}_{7}\right)(\mathrm{cm})$ & GR (cm.day ${ }^{-1}$ ) & SGR (\%.day $\left.{ }^{-1}\right)$ \\
\hline $\mathrm{K}$ & $0.72 \pm 0.0346$ & $0.83 \pm 0.0599$ & $0.0150 \pm 0.00473$ & $1.93 \pm 0.544$ \\
\hline P1 & $0.71 \pm 0.0131$ & $0.79 \pm 0.0132$ & $0.0123 \pm 0.00149$ & $1.65 \pm 0.200$ \\
\hline P2 & $0.72 \pm 0.0606$ & $0.83 \pm 0.0545$ & $0.016 \pm 0.00138$ & $2.09 \pm 0.292$ \\
\hline P3 & $0.76 \pm 0.0269$ & $0.88 \pm 0.0477$ & $0.0175 \pm 0.00412$ & $2.13 \pm 0.426$ \\
\hline P4 & $0.71 \pm 0.0311$ & $0.84 \pm 0.0477$ & $0.0191 \pm 0.00349$ & $2.46 \pm 0.363$ \\
\hline
\end{tabular}
P4 treatment, while the lowest level was shown in P1.

Table 1. TGCG grouper larvae length growth

Table 2. TGCG grouper larvae weight growth

\begin{tabular}{ccccc}
\hline Treatment & Initial $\left(\mathbf{H}_{\mathbf{0}}\right) \mathbf{( g )}$ & Final $\left(\mathbf{H}_{\mathbf{7}}\right) \mathbf{( g )}$ & GR $\left(\right.$ g.day $\left.^{-1}\right)$ & SGR $^{-1} \%$.day $\left.^{-1}\right)$ \\
\hline K & $0.014 \pm 0.0030$ & $0.018 \pm 0.0063$ & $0.000464 \pm 0.0004758$ & $2.54 \pm 1.951$ \\
P1 & $0.012 \pm 0.0006$ & $0.014 \pm 0.0016$ & $0.000303 \pm 0.0001584$ & $2.30 \pm 1.072$ \\
P2 & $0.012 \pm 0.0005$ & $0.015 \pm 0.0009$ & $0.000411 \pm 0.0001217$ & $2.97 \pm 0.839$ \\
P3 & $0.013 \pm 0.0014$ & $0.016 \pm 0.0026$ & $0.000536 \pm 0.0002140$ & $3.65 \pm 0.994$ \\
P4 & $0.012 \pm 0.0011$ & $0.017 \pm 0.0030$ & $0.000679 \pm 0.0003423$ & $4.51 \pm 1.912$ \\
\hline
\end{tabular}




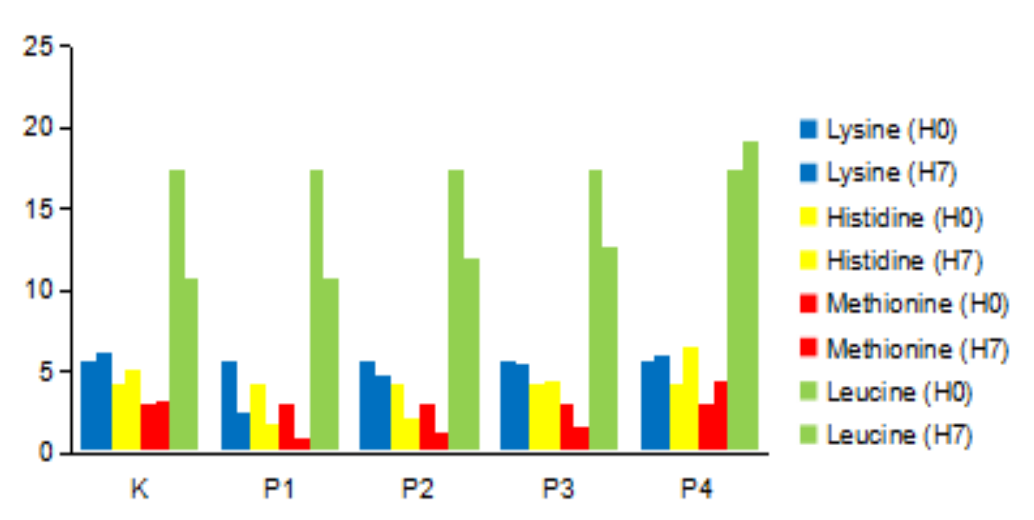

Figure 1. TGCG grouper larvae amino acid content

\section{Discussion}

\subsection{Larval length growth}

The absolute and specific length growth rate in all treatments showed no significant difference $(P>0.05)$. $P 4$ gave the best treatment, whereas $P 1$ gave the lowest length growth rates. However, the length growth rates data showed that Moina sp. powder is capable of substituting nauplii Artemia sp.

The P4 treatment became the best treatment, because Moina sp. powder had appealed color to get the larvae attracted, besides having good nutrient contents, particularly amino acids, and having strong smell. According to Zhang et al. (2015), the excellent feed color which was suitable for increasing the feed ingestion rate and growth of grouper larvae, was the greenish feed color. This happened the greenish feed color was easily captured by the cone cell that dominated in the retina, thus making it easy to get recognized by the eye organ of larvae (White et al., 2004 in Zhang et al., 2015).

Moina sp. powder had strong smell,whi ch acted as an attractant to increase the feed ingestion rate of the larvae. The strong smell itself came from the high content of amino acids in the feed. According to Kotani et al. (2016), feed given in larvae with high amino acid contents would increase the attractant level on the feed, while nutrients, such as amino acids that showed good attractant were lysine, glutamic, histidine, serine, methionine, tryptophan, and isoleucine (Ambariyanto et al., 2013).

Moina sp. powder also had good nutrient and nutrition contents for the larval growth. This was in accordance with the test result of protein and amino acid contents in the feed, which was $38.35 \%$ in the crude protein content, $\quad 5.79 \%$ in lysine content, $1.35 \%$ in methionine content, $2.18 \%$ in histidine content, and $7.61 \%$ in leucine content. The good nutrition contents were used to enhance the TGCG larval growth rate, system organ development, especially the digestive system organ development, and improving the larval survival rate (Li et al., 2008). Moina sp. powder given in P4 treatment also tended to move much slower than any other feed following the aeration speed, thus making it easily to be captured and eaten by the larva. Mahjoub et al. (2011) stated that the grouper larvae would swim slower, when feed was given on the rearing tank. This larval swimming type was usually called the burst-sustained swimming type (Fuiman, 2002). Thus, it is important to give feed with slower movement than the larvae swimming speed.

P1 treatment showed the lowest growth rate, either in the absolute and the specific growth rate. This happened because of the high use of nauplii Artemia sp., compared with the Moina sp. powder. Nauplii Artemia sp. had low crude protein content and amino acid contents with less favorite living behavior by the fish larvae (Helland et al., 2000). Nauplii Artemia sp. had faster swimming speed than the grouper larvae and was positive phototaxis with light (Mudjiman, 1989). Therefore, nauplii Artemia sp. would gather at brighter place to survive. Whereas, the TGCG larvae tended to capture feed that moved horizontally and spreaded on the surface, since TGCG larvae had the vertical swimming habit for catching the feed (Mahjoub et al., 2011). These circumstance caused the decrease level of Nauplii Artemia sp. consumption and would decrease the TGCG larval growth.

\subsection{Larval weight growth}

The weight absolute and specific growth rate of TGCG larvae showed no significant 
difference in all treatments $(P>0.05)$. Thus, Moina sp. powder which was mixed with the commercial feed is able to replace nauplii Artemia sp., since feed substitution was feed replacement from the ordinary feed to the new feed which was as good as or better affect in larval growth than the ordinary feed (Fermin, 1991).

The weight growth on larvae, especially grouper larvae, did not give significant difference, because the larvae used the absorbed nutrition to body growth and organ development directly (Fuiman, 2002). In addition, the grouper larvae also directly used the absorbed nutrition for swimming, foraging, and adapting to the rearing environment (Jones, 2002). The TGCG larvae itself had the ability to grow quickly on the larval phase with burst-sustained swimming activity (Fuiman, 2002). This swimming activity was first encountered on D18-D20 stages, where the larvae already had completed dorsal fin spine and anal fin, after passing through the critical period in D17 (Ismi et al., 2014). Moreover, with the anal and dorsal fin were formed, larvae would often swim around the rearing area and avoid distraction fast (Ch'ng and Senoo, 2008).

The weight growth on larvae itself came from the added body mass, as the result of nutrition absorption that produced body metabolites (Fuiman, 2002). The added body mass was also caused by the reserved energy to survive. Thus, when all absorbed nutritions were directly used to swim, grow, and develop, then the growth would only occur on the length than weight (Jones, 2002). The weight growth would occur when the larvae had approached the juvenile phase. This happened because the absorbed nutritions would be more widely used for reserved energy in the development of certain organs, such as the reproductive organs, besides for growth (Jones, 2002). Effendie (2002) also stated that fish which had reached the mature phase would use the energy produced from the absorbed for developing, rather than growing.

\subsection{Larval amino acid content}

\subsubsection{Lysine}

The increased of lysine content in TGCG larvae, especially on P4, due to the increased feed consumption and the feed conditions favored by the larvae along with the increased length and eight growth. Moreover, the nutrient contents in the feed, particularly lysine, was high (5.79\%). The larval lysine content tended to be optimum, when compared to the minimum lysine content in D20-D30 larval stage, which was $2.30-3.04 \%$ (Cai-Juan et al., 2016).

The high lysine content in TGCG larvae was also found in treatment $\mathrm{K}$, which only used nauplii Artemia sp. as the feed for TGCG larvae. This happened because nauplii Artemia sp. was a live feed which was easy to recognize and digest or get overhauled by the larval digestive enzymes (Sorgeloos et al., 2001). Nauplii Artemia sp. also had low chitinous exoskeleton (Criel and Macrae, 2002). Therefore, enzymes in the larval middle part of digestive tract (midgut) were able to break down the feed fast, then get absorbed quickly in the larval back digestive tract (hindgut) (Rønnestad et al., 2007). In K treatment, larvae also kept eating nauplii Artemia $\mathrm{sp}$. and commercial feed, since there were no other kinds of feed given. This happened because TGCG larvae was the grouper opportunistic feeder type, since this larvae consumed anything that was existed on the rearing media, especially when the larvae were starving (Gibran, 2007).

The TGCG larvae lowest lysine content was found P1 treatment. This situation occured due to the larval preferences on the feed given, which chose the Moina sp. powder, rather than nauplii Artemia sp., although with lower percentage level and lower speed digestion than nauplii Artemia sp. (Sorgeloos et al., 2001). Moina sp. powder also had an interesting color, slow movement in the media rearing, having the levels of the amino acid lysine, and generating powerful atractant (Zhang et al., 2015; Kotani et al., 2016). In addition, the feed degradation was also hypothetically stated due to the direct mixing of Moina sp. powder with commercial feed. This condition would make the feed given degrade the nutrient quality. The feed degradation itself appeared as the result of the imperfect mixing without using any adhesive materials, such as binder agent (Guevara and Poveda, 2012). Therefore, the feed would not perfectly mixed and get wasted on the base of the rearing aquarium and was not be able to be eaten by the TGCG larvae.

\subsubsection{Histidine}

The histidine content in TGCG larvae was increased after given Moina sp. powder, particularly in P3 and P4 treatment. This increased content happened because Moina sp. powder had higher crude protein content than nauplii Artemia sp. the Moina sp. powder had $38.35 \%$ of crude protein content and $20.28 \%$ in nauplii Artemia sp. Therefore, the histidine content in Moina sp. powder was also higher than nauplii Artemia sp., which was $2.18 \%$ 
compared with $1.30 \%$ (Ovie and Ovie, 2006). The highest result was shown in the P4 treatment with the histidine content was $6.50 \%$. This amino acid content was higher enough compared with the larval histidine content requirement in feed, which was $0.83-1.23 \%$ (Cai-Juan et al., 2016). This happened because TGCG larvae was able to absorb nutrients from Moina sp. powder properly. This statement had been proven by that data of the optimal larval growth rate, either length or weight growth rate. Higher histidine content also occured in $\mathrm{K}$ treatment, which was only given a commercial feed and nauplii Artemia sp. This appeared because nauplii Artemia sp. was live feed favored by the larvae. This live feed was also highly digested inside the larval digestive system, which was still in primitive condition (Budianto et al., 2014).

The first (P1) and second (P2) treatment showed the decreased histidine content, compared with the initial histidine content in TGCG larvae. the final histidine content in $\mathrm{P} 1$ treatment was $1.84 \%$, while in P2 treatment was $2.19 \%$. This decreased content appeared because the Moina sp. powder given was lower than in P3 and P4 treatments. Although the nutrition content in Moina sp. powder was higher than in nauplii Artemia sp., but due to low doze given to the TGCG larvae, then it was not effective to increase the histidine content of the TGCG larvae. The decreased content may also was affected due to the durability and buoyancy of the feed. The artificial feed quality was affected by its durability, moisture content, and water stability. Furthermore, the feed given did not use binders to combine the feeds given. Hence, the durability would decrease that caused the feed was easier to sink and not getting eaten by the larvae (Guevara and Poveda, 2012).

Histidine amino acid in the larvae was able to boost the larval growth by stabilizing the $\mathrm{pH}$ in intramuscular tissue and increasing the muscle density that made up the fish meat. The Stabilized of the intramuscular $\mathrm{pH}$ was conducted by the existence of L-histidine derivative, which was called carnosine (Shiau et al., 1997). Carnosine improved the speed of supplying nutrients to cells, especially into muscle cells. Thereby, the combustion energy during metabolic activity would go well. In addition, the nutrients that were absorbed in the muscle cells also would get faster to increase the muscle mass and enhance the fish growth (Shiau et al., 1997; Li et al., 2008). The good absorption of nutrients would form the structure and texture of meat fish through the increased muscle mass. The good absorption in the muscle cells were also able to tighten the space muscle or the muscle distance on the meat. Thus, the meat would form with more compact structure and dense as well as with large muscle mass and directly increase the growth (Li et al., 2008).

\subsubsection{Methionine}

The methionine content of TGCG larvae at the end of the research increased along with the increasing percentage of Moina sp. powder given. This increasing happened due to the Moina sp. powder had high nutrition and nutrient content, such as $38.34 \%$ of crude protein, $5.79 \%$ of lysine, $1.35 \%$ of methionine, $7.61 \%$ of leucine, $2.18 \%$ of histidine, and $6.24 \%$ of arginine. Meanwhile, Artemia sp. contained $0.9 \%$ of methionine content, $6.1 \%$ of leucine, and $1.3 \%$ of histidine (Watanabe et al., 1983 in Ovie and Ovie, 2006).

The methionine content in $\mathrm{K}$ treatment was high, compared with the treatment of P1, P2 and $\mathrm{P} 3$, but it was unable to use well by the larvae. Moreover, the utilization of amino acids that were less than optimal was caused due to the limited ability of fish in using amino acids (Giri et al., 2009). P1 treatment showed decrease methionine content drastically. This happened due to the degradation of the feed quality of the Moina sp. powder, in which caused the feed that was already in the aquarium was easily sunk and did not have for the larvae to consume it. Therefore, the larvae occurred to have lower growth and methione content. The sinking feed itself happened because of the lack of the feed physical ability in the form of water stability. According to Khater et al. (2014), several terms needed by artificial feed to get qualified was the actual diameter, endurance, buoyancy, water content, water stability.

The methione content which was found high in the Moina sp. powder made the feed have strong scent. This strong scent of Moina sp. Powder came from the sulfur compounds, which contained in the feed. Thus, the feed would induce the stimulation of strong taste and odor for fish (Khasani, 2013). Sutterlin and Sutterlin (1970) in Borquez and Carquera (1998) gave a theory that the gustatory stimulus was generated by L-cysteine, where L-cysteine was formed from the metabolism of methionine. Cysteine and methionine metabolism produced 2-amino ethan mesulfonic acid or taurine, which played a role in the mechanism of chemoreseptor to detect the feed. The main function of taurine itslef was also important for vision ability and the development of the nervous system. 


\subsubsection{Leucine}

The leucine content in TGCG larvae after treatment dozes given had fulfilled the minimum standard of leucine in grouper larvae, which was $3.17-3.37 \%$ (Cai-Juan et al., 2016). Hence, the larvae would not experience any sypmtomps of starvation, when the nutrient contents in the environment reduced. On the contrary, the leucine content in larvae that was less than the minimum content would cause the decreased growth and decreased feed efficiency, along with decreased hormone insuline secretion and fat decomposition (Tan et al., 2016).

Based on the diagram in Figure 1, the leucine content of TGCG larvae which showed an increasing after the feed given was found on $\mathrm{P} 4$ treatment, which was reached up until $19.13 \% \quad$ (Figure 1). This occured because Moina sp. had good leucine content, which was $7.61 \%$. This good leucine content would increase the protein synthesis and inhibit the protein degradation, thereby the larval growth would still run, although the larvae was in starvation condition (Wu et al., 2017). In addition, the optimum leucine content on the larvae would also make the larvae increase the digestive enzymes production for improving feed digestion (Tan et al., 2016).

P1 treatment appeared to be the lowest value of leucine content. This happened because the TGCG larvae preferred to eat Moina sp. powder in low level, thus making the leucine absoprtion in the larvae become lower than other treatments. The low absorption would lead to a decreased absorption of nutrients and increased larval feed conversion (Wu et al., 2017). Furthermore, the feed degradation was also thought to caused a decreased content of leucine. This happened because the feed combining between Moina sp. powder and commercial feed did not use binder. Binder was used as the perfect fish Feed Ingredient mixer to make the increased feed nutrient (Guevara and Poveda, 2012).

\section{Conclusion}

Moina sp. powder is compatible as good substitute candidate of nauplii Artemia $\mathrm{sp}$., as it was able to increased the larval length growth, even it had no significant difference in the larval weight growth. Moreover, Moina sp. mixed with commercial feed and given to the TGCG larvae was able to increase the lysine, histidine, methionine, and leucine amino acid contents in TGCG larvae.

\section{Acknowledgement}

Authors would like to thank to Mr. Apri Imam Supii, S.Pi., M.Si., as the field supervisor during the research and Professor Dr. Sri Subekti, drh., DEA., who had helped in writing this article.

\section{References}

Ambariyanto, A. Djunaedi, N. Taufiq S.P.J., R. Pribadi., D. Pringgenies. 2013. Absorbsi Asama Amino oleh Larva Ikan Kerapu Macan (Epinephelus fuscoguttatus). IImu Kelautan 18(4) : 188 - 189.

Arief, M., Triasih, I., Lokapirnasari, W.P. 2009. Pengaruh Pemberian Pakan Alami dan Pakan Buatan Terhadap Pertumbuhan Benih Ikan Betutu (Oxyeleotris marmorata Bleeker). Jurnal Perikanan dan Kelautan 1 (4) : 51 - 57.

Berge, G.E., H. Sveier., E. Lied. 1998. Nutrition of Atlantic Salmon (Salmo salar) : The Requirement and Metabolic Effect of Lysine. Comparative Biochemistry and Physiology Part A 120 : 479.

Borquez, A., Cerquirea, V.R. 1998. Feeding Behaviour in Juvenile nook, Centropomusundesimalis I. Individual Effect of Some Chemical Substances. Aquaculture 169: pp. 25 - 35.

Budianto, P., Suminto., Chilmawati, D. 2014. Pengaruh Chlorella sp. dari Hasil Pencucian Bibit Sel yang Berbeda dalam Feeding Regimes Terhadap Pertumbuhan dan Kelulushidupan Larva Kerapu Macan (Epinephelus fuscoguttatus). Journal of Aquaculture Management and Technology 3 (4) : 289 - 298.

Cai-Juan, S., R. Ramli., R.A. Rahman. 2016. Nutrients Requirements and Composition in A Grouper Fish Feed Formulation. The European Proceedings of Social and Behavioural Sciences (EpSBS). pp. 64 66.

Ch'ng, C.L., Senoo, S. 2008. Egg and Larval Development of a New Hybrid Grouper, Tiger Grouper Epinephelus fuscoguttatus $\times$ Giant Grouper E. lanceolatus. Aquaculture Sci. 56 (4) : 505 - 512.

Creswell, L. 2010. Phytoplankton Culture for Aquaculture Feed. Southern Regional Aquaculture Center (SRAC) Publication No. 5004. pp. 2 - 4.

Criel, R. J., Macrae, H. T. 2002. Artemia Morphology and Structure. Artemia : Basic and Applied Biology. T. J. 
Abatzopoulos, J. A. Breardmore, J. S. Clegg, and P. Sorgerloos (ed.). Kluwer Academic Publishers. pp. 29 - 30.

Cunha, M.E., H.Q. Ferreira, A. Barradas, P. Pousao-Ferreira, E. Cabrita., S. Engrola. 2009. Growth and Development of Dusky Grouper Epinephelus marginatus Larvae in Mesocosm of Semi-intensive Technology. Larvi'09 - Fish and Shellfish Larviculture Symposium No.38 Belgium. C.I. Hendry, G. Van Stappen, M. wille, and P. Sorgeloos (eds.). pp. 54 - 55.

Effendie, I. 2002. Bab XI : Pertumbuhan Ikan. Biologi Perikanan (Cetakan Ke V). Yayasan Pustaka Nusantama. Yogyakarta.

Fuiman, L.A. 2002. Special Considerations of Fish Eggs and Larvae (Ch. 1). Fishery Science : The Unique Contributions of Early Life Stages. L.A. Fuiman and R.G. Werner (eds.). Blackwell Publishing Company : Oxford. pp. 27 31.

Gibran, F.Z. 2007. Activity, Habitat Use, Feeding Behavior, and Diet of Four Sympatric Species of Serranidae (Actinopterygii : Perciformes) in Southeastern Brazil. Neotropical Ichthyology, 5(3) : 390 - 392.

Giri, I Nyoman Adiasmara., Alifiah, Sarah Sentika., Ketut Suwirya., Muhammad Marzuqi., 2009. Kandungan Asam Amino Lisin Optimal Dalam Pakan Untuk Pertumbuhan Benih Ikan Kerapu Sunu, Plectropomus leopardus. Jurnal Riset Akuakultur 4 (3): 357 - 366.

Guevara, W.A., Poveda, C.M. 2012. Effect of Binder Type and Concentration on Prepared Feed Stability, Feed Ingestion, and Digestibility of Litopenaeus vannamei Broodstock Diets. Aquaculture Nutrition. pp. 1 - 3.

Harli, M. 2008. Asam Amino Essensial. http://www.suparmas.com. Accessed 20 April 2010 (online).

Helland, S., G.V. Triantaphyllidis, H.J. Fyhn, M.S. Evjen, P. Lavens., P. Sorgeloos. 2000. Modulation of The Free Amino Acid Pool and Protein Content in Populations of The Brine Shrimp Artemia spp. Marine Biology 137 : $1010-1012$.
Hopkins, K.D. 1992. Reporting Fish Growth : A Review of The Basics. Journal of The World Aquaculture Society 23 (3) : 175 177.

Ismi, S., Asih, Y. N., Kusumawati, D. 2013. Peningkatan Produksi dan Kualitas Benih Ikan Kerapu Melalui Program Hibridisasi. Jurnal IImu dan Teknologi Kelautan Tropis 5 (2) : 333 - 342.

Ismi, S., Asih, Y. N., Kusumawati, D. 2014. Peningkatan Produksi dan Kualitas Benih Kerapu dengan Program Hibridisasi. Jurnal Oseanologi Indonesia 1(1) : 1 - 5.

Jones, C.M. 2002. Age and Growth (Ch. 2). Fishery Science : The Unique Contributions of Early Life Stages. L.A. Fuiman and R.G. Werner (eds.). Blackwell Publishing Company : Oxford. pp. 56 - 58.

Khasani, I. 2013. Atraktan Pada Pakan Ikan; Jenis, Fungsi dan Respons lkan. Jurnal Media Akuakultur 8 (2) : 127 - 133.

Khater, E.G., A.H. Bahnasawy., S.A. Ali. 2014. Physical and Mechanical Properties of Fish Feed Pellets. J. Food Technol. 5 (10) : 2157 - 7110.

Kotani, T., H. Imari., A. Miyashima. 2016. Effects of Feeding with Frozen Freshwater Cladoceran Moina macrocopa on The Performance of Red Sea Bream Pagrus major Larviculture. Aquaculture Int. 24 : $183-187$.

Li, P., K. Mai, J. Trushenski., G. Wu. 2008. New Developments in Fish Amino Acid Nutrition : Towards Functional and Environmentally Oriented Aquafeeds. Review Article : Amino Acids. pp. 5 - 6.

Mahjoub, M.S., S. Souissi, F.G. Schmitt, F.H. Nan., J.S Hwang. 2011. Anisotropy and Shift of Search Behavior in Malabar Grouper (Epinephelus malabaricus) Larvae in Response to Prey Availability. Hydrobiologia 666 : 218 - 220.

Mudjiman, A. 1989. Udang Renik Air Asin (Artemia salina). Jakarta : Bhratara. pp. 17-29, 135 - 139.

Ovie, S.I., Ovie, S.O. 2006. Moisture, Protein, and Amino Acid Contents of Three Freshwater Zooplankton Used as Feed for Aquacultured Larvae dan Postlarvae. The Israeli Journal of Aquaculture Bamidgeh 58 (1) : 29 - 33.

Purwaningsih, S., Santoso, J., Garwan, R. 2013. Perubahan Fisiko-Kimiawi, Mikrobiologi dan Histamin Bakasang Ikan Cakalang 
Selama Fermentasi Dan Penyimpanan. Jurnal Teknologi dan Industri Pangan 24 (2) : 168 - 177.

Reed Mariculture Inc. 2003. Product : Otohime Fish Diet. http://reedmariculture. com/product_otohime_fish_diet.php\#t ab tech. Accessed 28 Desember 2016 (online).

Rønnestad, I., Y. Kamisaka, L.E.C. Conceição, S. Morais., S.K. Tonheim. 2007. Digestive Physiology of Marine Fish Larvae : Hormonal Control and Processing Capacity for Proteins, Peptides, and Amino Acids. Aquaculture 268 : 92 - 94.

Sari, I.P., Manan, A. 2012. Pola Pertumbuhan Nannochloropsis oculata Pada Kultur Skala Laboratorium, Intermediet, dan Massal. Jurnal Perikanan dan Kelautan 4 (2) : 123-127.

Shiau, C.Y., Pong, Y.J., Chiou, T.K., Chai, T.J. 1997. Effect of Growth on The Levels of Free Histidine and Amino Acids in White Muscle of Milkfish (Chanos chanos). Journal Agriculture Food Chemical. 45 (6) : 2103 - 2106.

Sorgeloos, P., P. Dhert., P. Candreva. 2001. Use of The Brine Shrimp, Artemia spp., in Marine Fish Larviculture. Aquaculture $200: 149$ - 152.

Sugama, K., Rimmer, M. A., Ismi, S., Koesharyani, I., Suwirya, K., Giri, N. A. ,Alava, V. N. 2013. Pengelolaan Pembenihan Kerapu Macan (Epinephelus fuscoguttatus): Suatu Panduan Praktik Terbaik. Monograf ACIAR No. 149a. Australian Centre For International Agricultural Research: Canberra. p. 66.

Tan, X., H. Li, Z. Huang, C. Zhou, A. Wang, C. Qi., S. Zhao. 2016. Effects of Dietary Leucine on Growth Performance, Feed Utilization, Nonspecific Immune Responses and Gut Morphology of Juvenile Golden Pompano Trachinotus ovatus. Aquaculture 34 : 3 - 5.

Vandamme, D. 2013. Chapter 1 : Harvesting as A Key Challenge for Sustainable Microalgae Productions. Flocculation Based Harvesting Processes for Microalgae Biomass Production. Dissertation. Faculty of Bioscience Engineering Van de $\mathrm{Ku}$ Leuven University Belgium. pp. 17 - 25.
Walton, M.J., Cowey, C.B., Adron, J.W., 1982. Methionine Metabolism In Rainbow Trout Fed Diets Of Differing Methionine And Cystine Content. J. Nutr. 112 : 1525 1535.

World Wildlife Fund (WWF) Indonesia. 2015. Budidaya Ikan Kerapu Macan Sistem Keramba Jaring Apung. Better Management Practices : Seri Panduan Perikanan Skala Kecil 2 : 23 - 26.

Wu, C., L. Chen, Z. Lu, J. Gao, Y. Chu, L. Li, M. Wang, G. Zhang, M. Zhang., J. Ye. 2017. The Effects of Dietary Leucine on The Growth Performances, Body Composition, Metabolic Abilities, and Innate Immune Responses in Black Carp Mylopharyngodon piceus. Fish \& Shellfish Immunology 67 : 425 - 426.

Zhang, J., H. Guo, Z. Ma, S. Jiang, K. Wu, Y. Li., J.G. Qin. 2015. Effects of Prey Color, Wall Color, and Water Color on Food Ingestion of Larval Orange-Spotted Grouper Epinephelus coioides (Hamilton, 1822). Aquacult Int. : 4 - 8. 